\title{
Livestock, land use change, and environmental outcomes in the developing world
}

\author{
R.W. Blake and C.F. Nicholson ${ }^{2}$ \\ Departments of Animal Science' and Applied Economics and \\ Management ${ }^{2}$, Cornell University, Ithaca, NY 14853 USA
}

\section{Demand drivers and linkages}

Rapid predicted worldwide growth in demand for animal products to 2020, the so-called "next food revolution" in animal agriculture, portends complex interactions among people, biological and geophysical resources, and economic objectives. Consumer demand for beef and pork is expected to increase by $2.8 \%$ per year, somewhat slower than demand growth for poultry meat $(3.1 \% / \mathrm{yr})$. Demand for dairy products is predicted to grow fastest, at 3.3\%/yr (Delgado et al., 1999). More people with greater per capita incomes, primarily urbanites in developing countries, are expected to purchase about $70 \%$ more meat and $90 \%$ more milk than they did in 2000 . A restructuring of global food demands is expected: in contrast to current patterns, most $(>60 \%)$ global production of meat and milk will be consumed by households in the developing countries (Cranfield et al., 1998; Delgado et al., 1999). This consumption shift will bring another major change: the livestock sector would become the dominant value share of global agricultural output. The key drivers of this change are income growth, population growth, urbanization, and increased opportunities for trade (Figure 9.1).

This future food demand scenario involves two elements of the socalled "critical triangle" of development (Vosti, 1995), the alleviation of poverty (by increasing food production and food security) and the economic growth to achieve it. Correspondingly, greater demand for products of animal origin signifies a critical development opportunity for producers, especially small-scale farmers in developing countries who rear the majority of the world's livestock. However, economic and poverty-alleviating objectives also confront competing goals and environmental costs that constitute the triangle's third element: factors that sustain, or that may threaten, the environment. For example, demand increases for meat from non-ruminants (poultry and swine) especially signify greater pollution from confinement systems and more land to produce feed grains, while greater demand for beef would stimulate more pasture use of land. 
Figure 9.1.

Key drivers of livestock product demand, stocks of land, and important feedback loops. The dashed growth linkages loop indicates that livestock ownership promotes income growth for smallholder farmers in the developing world. The solid livestock assets loop indicates that income growth can lead to the desire to own more livestock assets. The profitability of livestock and their numbers influence the conversion of land from other uses to livestock production (grey dashed arrows).

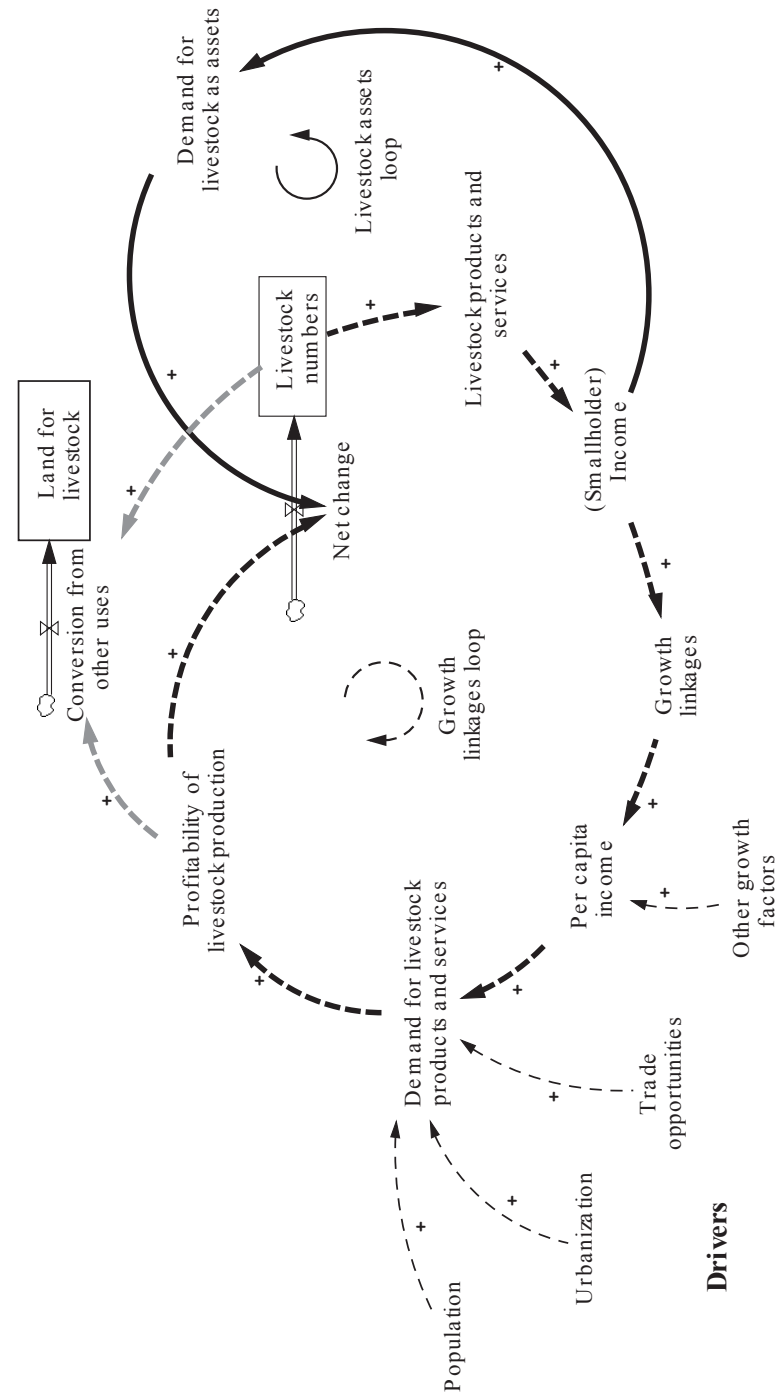

Selected potential impacts of increased demand for livestock products are illustrated in Figure 9.1. The key drivers result in additional demand for livestock products, which increases the profitability of livestock production. This, in turn, results in additional land being used for livestock and a larger global inventory of livestock. The development opportunities for smallholders are illustrated by the "growth linkages" loop, which relates an inventory with more animals to higher incomes for smallholders, whose spending of it generates additional income for other groups. In situations where the attractiveness of alternatives is low, increases in smallholder income can also be used to increase livestock numbers even further (the "livestock assets" loop). More 
livestock and land devoted to livestock production have potential negative environmental impacts through land conversion (e.g., forest clearing for pastures) and reductions in the productivity of land used for livestock, which results in the need for additional land clearing. Management strategies that conserve soil properties and support efficient nutrient cycling may offset degradation pathways, and increases in animal and land productivity may reduce the incentives for land conversion.

We identified some of the environmental risks, and recuperative effects, of animal agriculture in a recent article (Nicholson et al., 2001) noting, however, that environmental conditions in developing countries will likely worsen before they might improve (Alexandratos, 1995, with world population growing daily by about 250,000 people, it may be unrealistic to expect improvement in environmental conditions). That article focused on the impacts of forest conversion to pasture in Latin America, biological diversity in East Africa, and global greenhouse gas emissions from livestock production. This presentation complements that previous one, focusing more broadly on the ecosystem impacts of conversion of land to agricultural uses. We concentrate on systems with ruminant livestock, discuss the linkages to growth in animal products demand, and identify appropriate policy and research.

A key question is "How can (should) international agricultural researchers, the development community, and policy makers support the beneficial aspects of the growth in demand for animal products while minimizing negative environmental outcomes?" The productivity of land and livestock must be improved in an economically and environmentally reasonable way to feed a human population whose growth is a primary force threatening Earth systems. Achieving these goals involves tradeoffs because win-win outcomes, where the ecosystem impacts accompanying livestock-related household activities are inherently neutral or favourable, may be realistically few. Thus, a second key question is "Who should pay, directly or indirectly, for changes in agricultural production practices to reduce or mitigate environmental impacts?" Furthermore, the characteristics of specific situations vary greatly, implying the need for site-specificity in research and policy initiatives. A case in point: whereas pollution from excess nutrients (and microbes) from animal waste is a problem in developed countries, many are the cases in the developing world where too few nutrients, not too many, constrain agricultural sustainability. For example, reducing the $\mathrm{P}$ content of excreta from swine with dietary phytase helps control $\mathrm{P}$ transfers to the environment (e.g., pollution). However, in tropical locations where manure is fertilizer, swine manure with normal high $\mathrm{P}$ content is premium fertilizer, especially for low-P soils or crops with a high requirement. Hence, 
specific cases and system complexity demand specific information, research knowledge, and policy interventions. General recommendations, therefore, may be inappropriate or ineffective. Also, agricultural research and development policies alone may be insufficient to resolve these problems if dominant "root causes" lie elsewhere. For example, population growth and increases in per capita resource use may prove to be far more significant an environmental problem than land conversion from livestock (Meadows, 2002). However, projections of population growth and assessments of its impacts differ. Therefore, we focus on examination of current evidence about impacts of livestock in the shorter run, without endorsing a particular view about the future in the longer term (50$100 \mathrm{yr})$.

The remainder of this chapter consists of three sections. The first section summarizes the environmental and ecological impacts of land conversion, emphasizing change from natural habitats to agricultural use (but also notes that intensification of existing agricultural systems involves similar effects and mechanisms). The second section discusses the environmental impacts and tradeoffs for the case of expanded beef production in the western Brazilian Amazon. This case demonstrates the desirability of site-specificity for research and policy design and the potential usefulness of systems modelling for ex ante evaluation of alternative interventions. The final section concludes with an overview of research and policy recommendations, noting the potential complexity of using agricultural technologies to reduce environmental impacts of livestock production.

\section{Ecological and environmental impacts of land conversion}

\section{Relationships stemming from land conversion}

Increased livestock production has a number of potential negative environmental consequences. Among these, the conversion of land from natural habitats to agricultural uses more generally, particularly in tropical forest areas, has been a key cause for concern for the past few decades. The key relationships among livestock production, land use change, and environmental outcomes are shown in Figure 9.2. Land use conversion from forest to pasture is driven by incentives for livestock production (which are increased by livestock demand), limited alternatives to livestock production in these areas, and perhaps more importantly, economic inequality and poverty that create incentives for forest clearing by migrants. Land is also cleared for cropping, and conversion of land from pasture to crops (and vice versa; Nicholson et al., 1995). Clearing forest land reduces biodiversity and ecosystem services (e.g., pollination, pest control, flood control and water release). Current pasture management practices often 
Figure 9.2.

Relationships among livestock, land use change, and environmental outcomes. Dark grey arrows indicate key environmental or ecological impacts.

Light grey arrows indicate effects on conversion of land to pasture. Dashed arrows indicate effects related to soil nutrient cycling. The polarity of individual effects is indicated as positive (+) or negative $(-)$. $[C L=$ crop land; $\mathrm{GG}=$ greenhouse gases; $\mathrm{GGC}=$ greenhouse gas concentration; $\mathrm{P}=$ pasture; $\mathrm{PL}=$ pasture land].

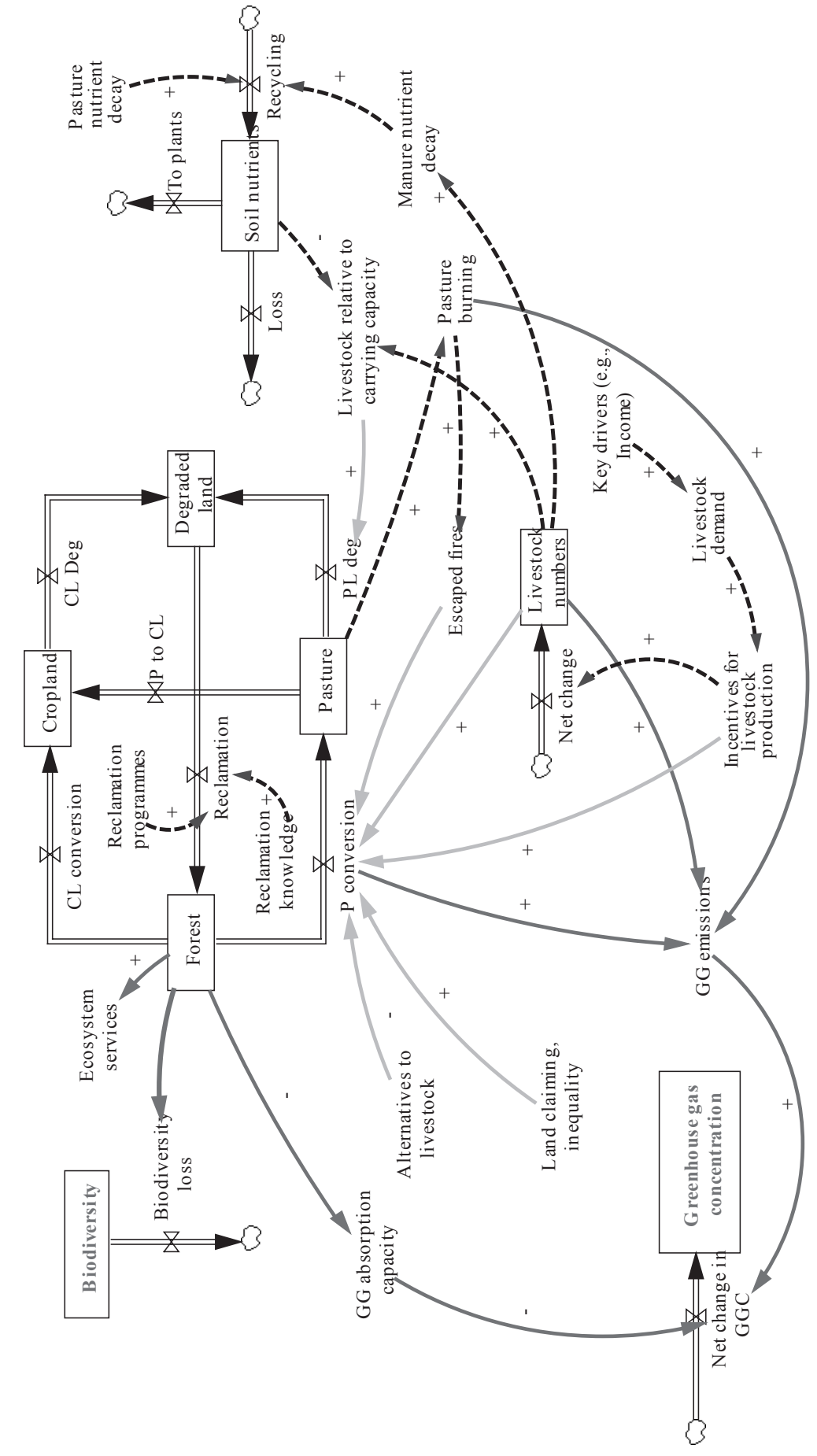


result in land degradation, which results in the need for more forest clearing, and pasture burning to promote regrowth and nutrient cycling leads to additional forest losses from accidental fires. The connection between land use change and greenhouse gas emissions is also indicated. Forest clearing (often through burning) releases large amounts of $\mathrm{CO}_{2}$ to the atmosphere, and greater livestock numbers also increase greenhouse gas emissions. At the same time, the ability of terrestrial ecosystems to absorb gases (especially $\mathrm{CO}_{2}$ ) is reduced by forest clearing.

The ecological literature provides quantitative estimates of the magnitude of some of these impacts and their importance. According to some observers, human demands on nature already may have exceeded regenerative capacity of the biosphere, which may bring an end to rapid agricultural expansion within 50 years (Tilman et al., 2001 a; Wackernagel et al., 2002). "Just as demand for energy is the major cause of increasing atmospheric greenhouse gases, demand for agricultural products may be the major driver of future non-climatic global change" (Tilman et al., 2001 a). Various forecasts, differing in degree but not in direction (Laurance, 2001; Laurance et al., 2001; Tilman et al., 2001a; Vitousek et al., 1997), anticipate important losses of habitat, biodiversity and ecosystem services by transforming more land to feed humankind, especially in Latin America and subSaharan Africa. These environmental modifications, involving greater inputs of $N$, $\mathrm{P}$, water and pesticides, can affect economic returns in a variety of agricultural systems, including high input-output animal monoculture, integrated crop-livestock systems (e.g., smallholders), and modest-performance extensive systems (e.g., grazing). However, the extent of these economic effects in both the long term and the short term often is not well documented or acknowledged. General impacts of land conversion described in the literature include nutrient loading, agrochemical pollution, acidification, salinisation, eutrophication of surface water, emissions of greenhouse gases, and irreversible species extinctions. For livestock production systems in the developing world, greenhouse gas emissions, nutrient losses to the environment, and species extinctions are of greatest importance. Furthermore, substituting pastures or crops for forest cover increases albedo (the ratio of reflected to incident light), which may reduce precipitation and increase temperatures (Vitousek et al., 1997). The remainder of this section focuses on the relationships between land use, habitat loss and fragmentation and biodiversity losses, and agroecological options for producing food and ameliorating the longterm environmental costs of doing so.

\section{Habitat loss and fragmentation}

Simplifying natural ecosystems (and biogeochemical cycles of $\mathrm{C}, \mathrm{N}$ 
and P) with agricultural uses initiates processes that lead to biomass losses and species losses and substitutions: The abundance of biodiversity is directly related to the abundance of biomass. We noted in our previous paper that relationships between forest conversion and biodiversity have often been oversimplified, and that the dynamics between pasture, trees and forest remnants are complex. However, conversion of forest to pastureland is an important source of biodiversity loss from changes in regional climate, nutrient dynamics and biotic exchange, which implies the food revolution in animal agriculture could increase these losses. Burning is a principal pathway for initial forest clearing that releases nutrients stored in above-ground biomass. However, routine pasture management in many parts of Latin America involves periodic burning to promote pasture regrowth, control weeds, and release nutrients from senescent plant biomass. Unfortunately, about $40 \%$ of these pasture and slash fires escape to adjacent areas (Kauffman et al., 1998). Burning practices resulted in about 17 million hectares of uncontrolled fires in Indonesia and Latin America in 1998. The estimated \$19 to \$25 billion cost of these fires (Cochrane, 2001), presumably mostly in sacrificed forest products, may greatly undervalue total losses also in habitat, species and atmospheric load. More light through more penetrable burnt forest canopy causes warming, which increases water losses and makes forests more fire-prone. In addition to destruction of habitat, burning pastures releases large quantities of $C$ to the atmosphere. Therefore, pasture management in which less land is burned less frequently would protect forests and the services they provide.

Lost and fragmented habitats make it more difficult for plants and animals to meet needs and survive environmental vagaries (Laurance, 2001; Sala et al., 2000). Although pollen flow could partly compensate fragmentation losses in certain cases, it requires that welfare and behavioural (spatial) responses of pollinators are assured (White et al., 2002). Also, fragmented forest is more susceptible to fire from 'vegetation breeze', where clearings large and small draw moisture from the forest, substituting it with dry air. Dried forest edges are more likely to ignite when nearby pastures are burned (Laurance et al., 2002).

Unfortunately, besides altered land use "the strength of interactions among drivers in their effects on biodiversity is virtually unknown" (Sala et al., 2000). These interactions are poorly understood in low as well as high rainfall ecosystems. Zonal effects of cattlepost systems in the semi-arid Kalahari (Botswana) produce an environmental tradeoff between vegetation sacrificed and the amount of rangeland biodiversity that is retained (Perkins, 1996). Supported by borehole water, these dynamic systems rely on herd mobility and flexibility in a manner similar to wildlife. Water availability increases the area that 
can be used by cattle but results in severe land degradation due to excessive nutrient loading within $50 \mathrm{~m}$ of watering locations. This modest sacrifice in habitat permits cattlepost managers to make productive use of the remaining rangeland without significant degradation of that resource, which is now known to respond favourably (e.g., greater plant survival and productivity) to continuous grazing pressure and unfavourably to the lack of it (Oba et al., 2000). In fact, land productivity of the cattlepost system exceeded that from subsidized commercial beef systems when all herd outputs (milk, beef, and draft power) were accounted (Perkins, 1996).

\section{Cascading effects on species shifts and biodiversity losses}

Transforming lands with marginal fertility to agriculture can have a large global effect because these locations sustain ecosystems of high diversity. About 18\% of mammals, $11 \%$ of birds and $8 \%$ of plant species may currently be at risk of extinction from land conversion (Vitousek et al., 1997), which implies significant agroecosystem losses such as wild genes for resistance to plant pests and disease, pollination by birds, insects, bats and other mammals (from neighbouring ecosystems), and pest outbreak control by predators (Tilman, 1999). Forest disturbance is one pathway that adversely affects understory insectivores, especially birds with limited dispersal ability whose vulnerability is heightened to forest edge effects, isolation and random events (Sekerciouglu et al., 2002). Species least affected are those able to utilize clearings. Biological invasions also reduce species diversity and increase pest losses in crops and livestock (Pimentel ef al., 2000). Scarce soil nutrients are more completely utilised in high diversity systems, which constitutes a barrier to invading species (Tilman, 1999). Conversely, unconsumed nutrients may favour pathogens and pests, which may be a consequence of indiscriminate or uncalibrated fertilization of food and forage crops. For example, high soluble $N$ in fertilized plants can invite larger populations of sap-feeding insects (Matson et al., 1997), a phenomenon that may also apply to forage grasses. Differing from past recommendations relying on more fertilizer to produce more rice, today growers are sometimes urged to moderate their $\mathrm{N}$ use to reduce risk of yield losses from pest outbreaks. High external nutrient inputs on arable lands in rainy climates and erosion losses in overstocked arid lands also lead to less diversity. Increases in farm land have shrunk habitats, populations of non-domesticated animal species and their range of dispersal. This process imposes selection pressures against large species with low dispersal potential, which increases threats (e.g., weeds, pathogens and competitive microbes) to the environment and to agriculture (Western, 2001).

Species extinction is partly governed by the interaction between dispersal ability, habitat loss and climate change. Greater rainfall 
variability affects habitat and climate change and has resulted in population fluctuations and extinction of butterflies (McLaughlin ef al., 2002). Possibly exacerbated by substitution with grasses, larvae mortality rates increased from shorter overlap with the required plants. Environmental bottlenecks also invoke biological mechanisms of species loss. Predisposition to extinction is increased by inbreeding when the effective population size becomes small and insular, which results in losses of alleles with large effects on fitness and survival (Keller and Waller, 2002). Inbreeding depresses birth rate, birth weight, offspring survival, and resistance to disease and other stressors (e.g., predators), which makes individuals more likely to perish from vagaries of the environment. Less heterozygous sheep had more parasitism and were less likely to survive untreated helminthic infestation than more heterozygous individuals (Keller and Waller, 2002), an important consequence for producers who cannot afford chemical control.

Mitigating biodiversity losses requires clear understanding of the mechanisms in each case. On a global scale, this means a set of management porffolios matched efficaciously to biological and socioeconomic needs by eco-region (Sala et al., 2000). Productivity and diversity may be enhanced by complementarities and net favourable interactions among species, including resistance to pathogens and invaders, especially where nutrients are scarce (Western, 2001). Cropping with a species mixture may be useful (Tilman, 1999). This strategy is used by crop-livestock farmers in Ethiopia's low-rainfall Harar highlands (Kassa et al., 2002), who densely sow maize and sorghum and selectively thin maize (sorghum) for forage if rainfall is low (high). Species complementarity and niche differentiation, for example from a mixture of forage genotypes, could exploit warm/ cool and rainy/dry seasons, and deep/shallow soil nutrient profiles.

\section{Agroecological options: given where we are, what can we do?}

In summary, an important agroecological goal in the long-term is to assure sufficient land and resources for survival of most species (Vitousek et al., 1997). This requires learning how ecosystems interact with, and recover from, environmental disturbances, including agriculture. In addition to converting less land to agriculture, it also means curtailing the cascade of interactions on habitats, species extinctions and complementarity losses, lost ecosystem services, and nutrient stocks (e.g., for food production, diversity, barriers to pests and pathogens, waste control). Western (2001) offered useful principles (Table 9.1) for reducing these environmental costs. Based on this guidance, a nutrient management research portfolio should address: 1) effective nutrient cycling between soils, plants and animals; 2) improved nutrient use efficiencies of plants and animals; 3) 
improved management of nutrient stocks and soil fertility; and 4) alternative uses of grazing land, especially in a more diversified agriculture that meets economic needs of producers. Other considerations are to recruit ecosystem services from other species by bridging habitat fragments with multi-use land buffers and corridors (e.g., along fence lines on pasture landscape), to plan agriculture with less land fragmentation and more ecosystem types with biodiversity hot spots preserved, the judicious use of agrochemicals and manure, fallow management (e.g., cover crops), development of productive crops with lower requirements for water, nutrients and pesticides, and integrated pest and pathogen management. However, achieving outcomes that are more environmentally sound often will require economic incentives, especially for small- and medium-sized farmers who are our key environmental stewards (Pinstrup-Andersen, 2001). The need for economic incentives raises the question of the political feasibility for successful implementation of these strategies on a sufficiently large scale to have notable impact.

Table 9.1.

Principles for

conserving

ecosystem

processes (from

Western, 2001).

Maintain or multiply Minimize Mimic

Species richness, structural symmetry, key species/

functional groups

Internal regulatory

processes and interactions

(e.g., predator-prey)

External diversifying forces

Landscape

homogenisation

Large habitat areas and spatial linkages between ecozones

Ecological gradients and ecozones

\section{Pasture-based cattle production in Brazil's arc of deforestation}

The foregoing discussion of impacts of land use change and potential actions is useful, but can be complemented by a discussion of impacts and responses for a specific area. Land use change and policy in the Brazilian Amazon, a topic of current debate (Laurance et al., 2001; 2002), has been of great concern for at least the past two decades, and illustrates many of the general concepts identified above. Thus, 
we use results from studies of dual-purpose (milk-beef) and beef cattle systems in the Brazilian Amazon to discuss the potentials and limitations of modifying livestock production systems to achieve more desirable environmental outcomes.

The Amazon region of Brazil is essential to global biodiversity, to climate and regional hydrology, and to $\mathrm{C}$ stores by harbouring about $40 \%$ of the world's tropical rainforest. This region is also home to about one-fourth of the national herd of about 170 million cattle, which is currently reared extensively on approximately 43 million hectares. Forest losses are especially high in the four-state "arc of deforestation", including the westernmost Acre State, and could reach $5000 \mathrm{~km}^{2} / \mathrm{yr}$ (Cochrane, 2001). This transformation is driven by population growth, logging and mining, spatial effects of development (e.g., roadways), and fire. Current trends suggest more habitat fragmentation, less rainfall from less evapo-transpiration and sequestered atmospheric moisture from smoke, higher land surface temperatures, species losses, and heightened risk of forest fires abetted by the drying effect of vegetation breeze (Laurance et al., 2001 ; 2002). Although widespread pasture degradation is well documented in the eastern Amazon, the farm management practices (e.g., stocking rates, soil-plant nutrient relationships, burning frequencies) causing it have not been adequately studied. Thus, it is currently unknown to what extent alternative management would control degradation losses (and, therefore, reduce pressure for additional forest clearing).

To reduce environmental losses, Laurance and co-workers (2001) favour farm livelihoods earned from agroforestry and perennial cropping over "fire-maintained cattle pastures and slash-and-burn farming." Of course, these alternatives need to be economically attractive to be adopted, and the available evidence suggests limited potential (Vosti and Valentim, 1998). Alternatively, more intensive cattle production has been proposed to improve economic returns to labour and land while reducing deforestation pressure. However, greater profits from more intensive management (e.g., more beef and milk from more dietary inputs and labour) may provide incentives for additional land clearing. Pasture and cattle activities in Acre were estimated to be more profitable than other alternatives, which implied economic incentives to clear more forest (Carpentier et al., 2000). Clearing was influenced by labour supply and access to markets.

Recent studies explored soil-plant-animal nutrient relationships, milk and beef potentials, and economic constraints of pasture-based cattle systems in Acre (the Western Amazon), where large fire-managed paddocks are lightly stocked with animals not differentiated by nutritional requirements. Findings indicated relatively low nutrient exports in animal products of $6 \mathrm{~kg} \mathrm{~N} / \mathrm{ha}$ and $3 \mathrm{~kg} P / \mathrm{ha}$ (compared to 
rice, beans or coffee crops) from farms with two 450-kg animal units per hectare (Rueda et al., 2004). In contrast to studies in the Eastern Amazon, pasture productivity has been maintained for two decades. This relative longevity may result from better soil characteristics than elsewhere in Amazonia, but also from low stocking, which results in more-than-adequate pasture biomass availability, substantial nutrients recycled from leaf litter and less soil compaction. This evidence supports the idea that pasture management may play a key role in system sustainability. It also suggests there is potential for positive outcomes from research on alternative practices (and, in some cases, reclamation of degraded lands) for other parts of Amazonia.

The current cattle production system in the Western Amazon appears sustainable. However, improved access to beef markets in Lima, Peru and the Pacific region (through a recently completed highway) could create incentives for increased beef production in the region, implying that more intensive production systems may be needed to limit the ultimate extent of additional forest clearing. Substantial productive potential was identified for application of external nutrients to pasture to increase stocking rates and offtake. With herd nutrition based on accurate predictions of nutrients supplied by forages and required by animals (Tedeschi et al., 2002), this translated to greater net economic returns from labour-intensive (i.e., potentially land saving) technologies to produce beef (but was not profitable for milk), and not by improving individual performance by better supplementation of diets (Rueda et al., 2003). Although more labour would be required, beef production through judicious fertilization of grass-legume pastures and higher stocking rates may improve farm incomes and slow the rate of forest clearing.

However, the long-term dynamics of this intensification strategy are not known. Higher stocking rates imply shifts in the pools of nutrients to recycle from plant litter to readily decomposable animal excreta (Figure 9.3). To explore the potential impacts, a systems modelling approach can be useful. In a conceptual systems model, forage productivity and residual environmental health are represented as feedbacks among stocks and flows of four nutrient sources, soil, available pasture (forage) biomass, decaying pasture biomass, and decaying manure. The grazing-manure management pathway is especially important to herd productivity, external nutrient demand, and productivity and pasture health outcomes. Proper land allocations of manure through herd grazing management can reduce fertilizer requirements and maintain soil nutrient stocks, which supply plant requirements for growth. A key research question is the extent to which external nutrient inputs (e.g., mineral fertilizers) are required to sustain this system. Better knowledge of the sizes of the various nutrient pools and the rates affecting them (availability) would provide 
Figure 9.3.

Nutrient dynamics in the pasture-based cattle system of the Western Amazon of Brazil showing key nutrient pools and linkages between them. An increase in animals per land area increases the grazing rate, thus decreasing decaying pasture biomass with greater nutrient cycling through manure. The need for external nutrient inputs and system sustainability depend on the initial nutrient stocks and flow rates.

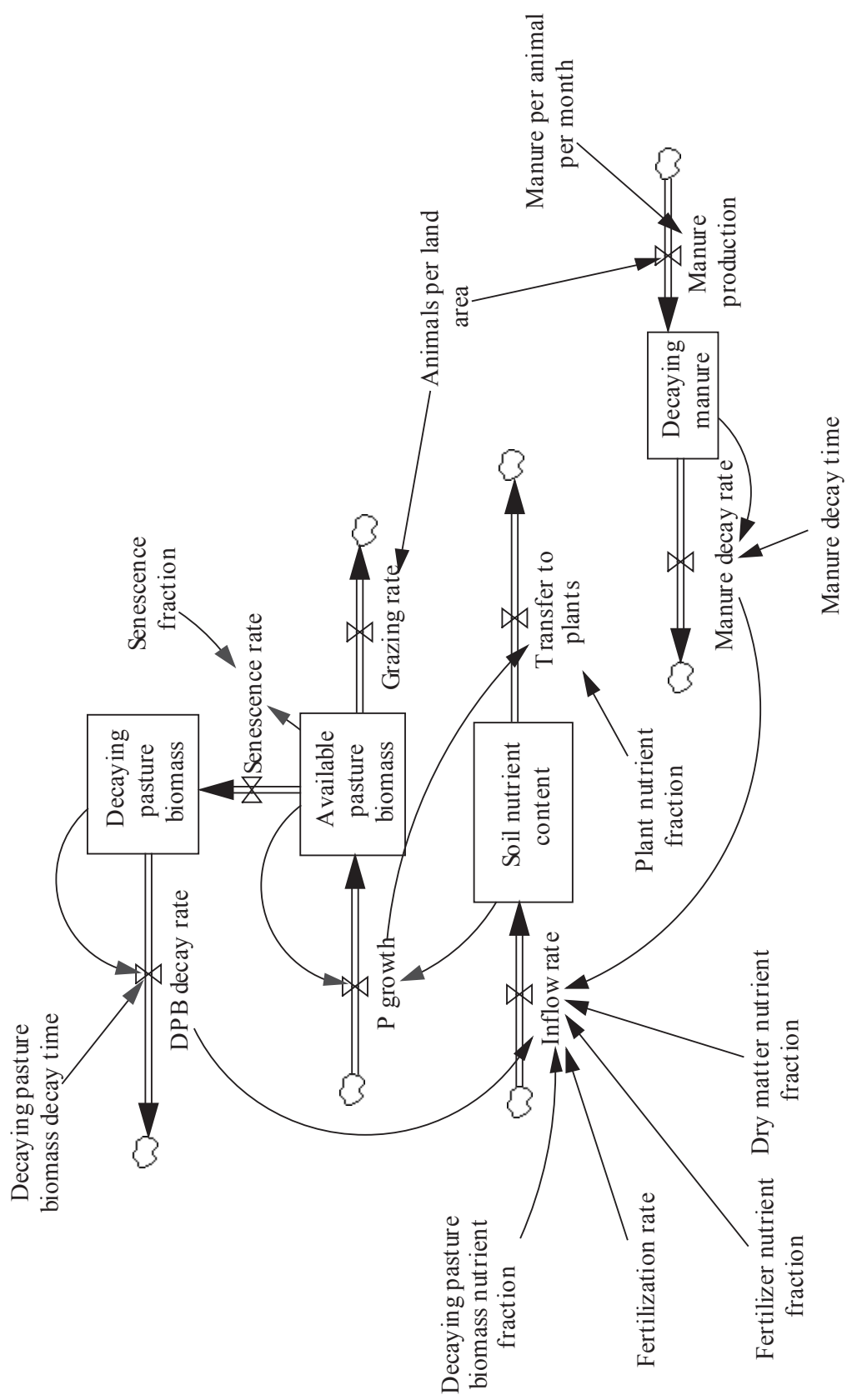


information crucial to more intensive management of the Acre production systems. However, it is again worth noting that beef demand is only one of several factors affecting land transformation and alternative agricultural technologies are unlikely to fully address its root causes (Nicholson et al., 1995; 2001).

Although additional studies to better understand the dynamics of nutrient stocks in the Western Amazon can facilitate better responses to increased market access for beef production, available information suggests that certain strategies may help reduce negative environmental impacts. The recommendations in Table 9.2 emphasize opportunities for better integrated nutrient management under current economic conditions.

Pastures and animals Biodiversity

Harvest pasture nutrients by intensive grazing; avoid burning

Design and build through pasturelands a bridge network of fragmentation-

Herd nutrition based on accurate predictions of forage quality and animal nutrient requirements ameliorating, diversified forest blocks and corridors with incomeearning potential (e.g.,

Table 9.2.

Group animals in paddocks Agro-ecosystem management opportunities for cattle systems in Acre, Brazil. according to their nutrient requirements natural barrier fences) to preserve wildlife and regenerate ecosystem services

Titrate stocking and herd size and provide drinking water to assure effective distribution of excreta across the landscape (to promote widespread nutrient recycling)

Fertilize in accordance with the nutrients extracted and recycled from excreta

Evaluate and utilize multi-species portfolios of grasses and legumes

Focus management on herd reproduction and herd performance, not individual performance

\section{Limitations of the technology toolbox}

To what extent can the development of agricultural technologies for cattle production systems in the Amazon region reduce the pressure 
for additional forest clearing? The multiple causes of forest clearing have already been mentioned, and these may, in fact, dominate attempts to increase (or maintain) the productivity of land and livestock. However, a more subtle challenge is that technologies that increase productivity may actually increase incentives to clear land. As Rueda and co-workers (2003) noted, profitable technologies that increase or maintain productivity of beef can reduce the need for land. However, if technologies are sufficiently profitable, they may result in incentives for additional forest clearing, so as to apply the new (more profitable) technology to a broader land base. The nature of this challenge is illustrated in Figure 9.4. Technology use depends on a number of factors, including the expected economic returns from doing so. If the technology increases the profitability of beef production, it creates incentives to clear additional land. If the technology is labour-intensive, and labour (for hire) is limited in the region, this may limit the impact of increased profitability on forest clearing (Angelsen and Kaimowitz, 2001). In the long-run, however, if the new technology is profitable enough, wages can rise and induce greater migration to the area, which will increase the availability of labour and, therefore, forest clearing. These basic principles apply broadly to many technological options, including those cited above. The basic result is that developing livestock production technologies that are profitable in the short run and do not exacerbate land use change is a major challenge.

\section{Information needs and recommendations}

More understanding is needed about the interaction of agricultural practices with environmental and ecological outcomes to develop practices that avoid further deterioration and restore accumulated damages. Models predicting habitat loss from conversion to agriculture and land degradation indicate that "a pool of species will eventually become extinct unless the habitat is repaired or restored" (Dobson et al., 1997). Studying restoration processes of degraded land would build understanding about ecological communities and agro-ecological function. Priority sites include ecosystems where agriculture was short-lived, such as forests cleared in the Eastern Amazon. Integrated agro-ecological strategies include improved nutrient management, illustrated above for the Western Amazon. Complementary strategies include bridging (restoring) forest fragments with hospitable fence line corridors and windbreaks of native species to facilitate wildlife dispersals and ecosystem services (Sekercioglu ef al., 2002; Tilman et al., 2001 b). Investments are needed in productive and environmentally friendly technologies, especially for small- and medium-sized farmers who are equally efficient as large-scale operators and wise stewards of the environment. The technology toolbox should include new innovations based on external inputs and 
Figure 9.4.

Relationships between technology adoption and forest clearing. Dashed pathways indicate key relationships between profitability and clearing. Heavy solid pathways indicate the relationships between productivities of land, labor and animals and clearing. Grey pathways indicate feedbacks between productivity, profitability and technology adoption.

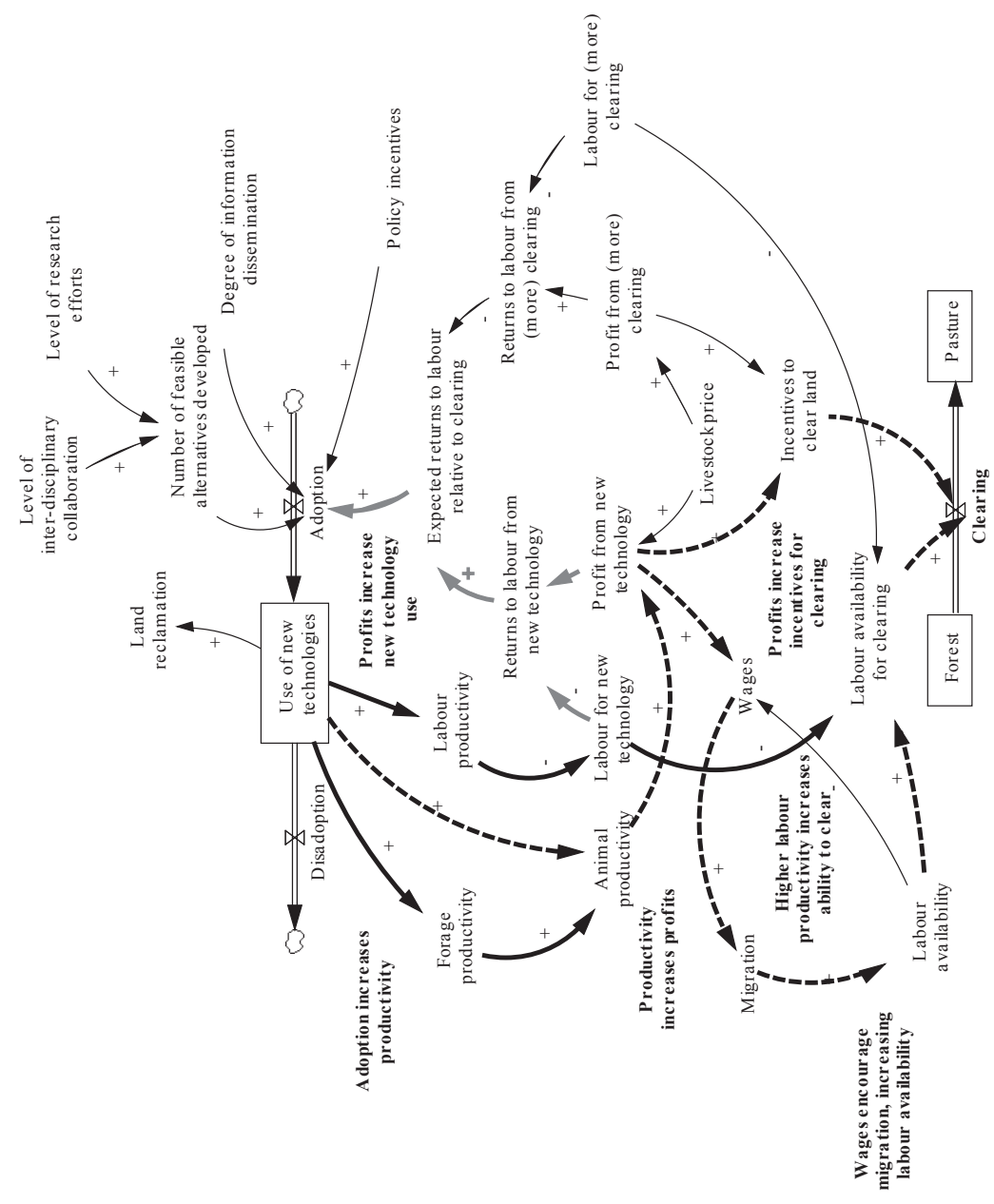


agroecological approaches that are sensitive to supplies of local labour, organic inputs, improved knowledge and farm management (Pinstrup-Andersen, 2001).

Despite incomplete information about the best animal agriculture responses to global food demand drivers, and ways to motivate such implementations, short-term actions as well as research investments are needed. It is unrealistic that rural households can (or should) fully bear the burden of environmental costs because win-win opportunities are probably limited. Thus, the main challenge involves connecting existing knowledge about how agro-ecosystems function to the effectiveness of candidate interventions in specific situations. There are essentially five types of interventions that can be undertaken. These include financial incentives provided to farm households to promote desirable ecosystem outcomes (or reductions in subsidies for harmful activities); research to develop profitable technologies with minimal undesirable environmental impacts (or that are restorative); prohibition or restrictions on harmful activities with effective enforcement, and education for stakeholder groups about the ecological and environmental consequences (negative, positive) of their actions. In certain cases, innovative institutional arrangements (e.g., modification of land use rights, access to credit or banking that reduces dependence on livestock assets) will also be necessary or desirable. It is likely that some combination of these will be most effective. Land tenure, taxation and economic policies are other mechanisms for mitigation and restoration; and better communication is also needed so that science is better utilized in policy making (Fernandez, 2002).

To examine more fully the effectiveness of potential interventions, it will be helpful to integrate existing disciplinary knowledge into conceptual or quantitative simulation models. Modelling of agricultural systems has become an important way to assess the potential for policy interventions to prevent or mitigate environmental consequences (Thornton and Herrero, 2001; Heerink et al., 2001). One general approach that can be usefully employed in this context is system dynamics (SD), a broadly applicable systems-based approach to problem solving (Sterman, 2000). Using SD, problems are expressed as a feedback (stock-flow) model that provides insights about how a problem behaviour developed over time and about which interventions or policies can provide a lasting solution to the problem. System dynamics is most appropriate for problems that are dynamically complex (evolve over time, are non-linear and governed by feedback), are long-term in nature, can be described by a relatively small set of "reference mode" behaviours observed in the real world, and can be described by flow processes (Vennix, 1996). The SD approach permits conceptual and quantitative modelling of dynamic 
problems, and has been previously applied to land degradation processes in sub-Saharan Africa (Brontkes, 2001). For successful application of these methods, it will be important to provide incentives to researchers from various disciplines, policy makers, development organizations, and farm households to work together to gain a broad perspective on the nature of both the problems and potential solutions. Because values, that is, the ultimate objectives to be achieved in response to the changes wrought by increased livestock demand, are likely to differ among the different disciplines (e.g., animal scientists, ecologists, economists), discussions of these values will be an important component of successful multidisciplinary research efforts.

\section{Acknowledgements}

We thank the following people for reading an earlier draft of this article and for their helpful suggestions to improve it: Duane Acker, G. Eric Bradford, Rod Heitschmidt and David Pimentel.

\section{References}

Alexandratos, N. (ed.) (1995). World Agriculture towards 2010: An FAO study. Chichester, UK: Food and Agriculture Organization of the United Nations and John Wiley and Sons Ltd.

Angelsen, A. and Kaimowitz, D. (2001). When does technological change in agriculture promote deforestation? In: Tradeoffs or synergies? Agricultural intensification, economic development and the environment. Edited by D.R. Lee and C.B. Barrett. CAB International Wallingford, UK, pp. 89-114.

Brontkes, T.S. (2001). Agricultural prices and land degradation in Koutiala, Mali: A regional simulation model based on farmer's decision rules. Economic policy and sustainable land use: Recent advances in quantitative analyses for developing countries. Edited by N. Heerink, H. van Keulen and M. Kuiper. PhysicaVerlag, Heidelberg, pp.151-168.

Carpentier, C., Vosti, S.A. and Witcover, J. (2000). Intensified production systems on western Brazilian Amazon settlement farms: could they save the forest? Agriculture Ecosystems and Environment 82:73-88.

Cochrane, M. (2001). In the line of fire. Understanding the impacts of tropical forest fires. Environment 43:28-38.

Cranfield, J.A.L., Hertel, T.W., Eales, J.S. and Preckel, P.V. (1998). Changes in the structure of global food demand. American Journal of Agricultural Economics 80: 1042-1050.

Delgado, C., Rosegrant, M., Steinfeld, H., Ehui, S., and Courbois, C. (1999). Livestock to 2020: The next food revolution. Food, Agriculture and Environment Discussion Paper 28, International Food Policy Research Institute (IFPRI), Washington, DC, USA. 
Dobson, A.P., Bradshaw, A.D. and Baker A.J.M. (1997). Hopes for the future: Restoration ecology and conservation biology. Science 277:515-522.

Fernandez, R.J. (2002). Do humans create deserts? Trends in Ecology and Evolution 17:6-7.

Heerink, N., Kuyvenhoven, A. and van Wijk, M.S. (2001). Economic policy reforms and sustainable land use in developing countries: issues and approaches. Economic policy and sustainable land use: Recent advances in quantitative analyses for developing countries. Edited by N. Heerink, H.van Keulen and M. Kuiper. Physica-Verlag Heidelberg, pp. 1-20.

Kassa, H., Blake, R.W. and Nicholson, C.F. (2002). The crop-livestock subsystem and livelihood dynamics in the Harar Highlands of Ethiopia. In: Responding to the increasing global demand for animal products - Programme and Summaries. International conference organised by the British Society of Animal Science, American Society of Animal Science and Asociacion Mexicana de Produccion Animal, held at the Universidad Autonoma de Yucatan, Merida, Mexico, 12-15 November, 2002. British Society of Animal Production, Penicuik, UK, pp. 74-75.

Kauffman, J.B., Cummings, D.L. and Ward, D.E. (1998). Fire in the Brazilian Amazon. 2. Biomass, nutrient pools and losses in cattle pastures. Oecologia 113:415-427.

Keller, L.F. and Waller, D.M. (2002). Inbreeding effects in wild populations. Trends in Ecology an Evolution 17(5):230-241.

Laurance, W.F. (2001). Future shock: forecasting a grim fate for the Earth. Trends in Ecology and Evolution 16:531-533.

Laurance, W.F., Cochrane, M.A., Bergen, S., Fernside, P.M., Delamonica, P., Barber, C., D'Angelo, S. and Fernandes, T. (2001). The future of the Brazilian Amazon. Science's Compass Policy Forum, 19 January, 291:438-439.

Laurance, W. F., Powell, G. and Hansen, L. 2002. A precarious future for Amazonia. Trends in Ecology and Evolution 17:251 252.

Matson, P.A., Parton, W.J., Power, A.G. and Swift, M.J. (1997). Agricultural intensification and ecosystem properties. Science 277: 504-509.

Meadows, D.M. (2002). Reflections on the dynamics of growth. Paper presented at the Annual Meeting of the System Dynamics Institute, June 4, 2002, Montebello, Quebec.

McLaughlin, J.F., Hellmann, J.J., Boggs, C.L. and Ehrlich, P.R. (2002). Climate change hastens population extinctions. Proceedings National Academy of Science 99:6070-6074.

Nicholson, C.F., Blake, R.W., Reid, R.S. and Schelhas, J. (2001). Environmental impacts of livestock in the developing world. Environment 43:7-17.

Nicholson, C.F., Blake, R.W. and Lee, D.R. (1995). Livestock, 
deforestation, and policy making: Intensification of cattle production systems in Central America revisited. Journal of Dairy Science 78:719-734.

Oba, G., Stenseth, N.C. and Lusigi, W.J. (2000). New perspectives on sustainable grazing management in arid zones of subSaharan Africa. BioScience 50:35-51.

Perkins, J.S. (1996). Botswana: fencing out the equity issue. Cattleposts and cattle ranching in the Kalahari Desert. Journal of Arid Environments 33:503-517.

Pimentel, D., Lach, L., Zuniga, R. and Morrison, R. (2000). Environmental and economic costs of nonindigenous species in the United States. BioScience 50:53-62.

Pinstrup-Andersen, P. (2001). Feeding the world in the new millennium: Issues for the new US administration. Environment 43:22-31.

Rueda, B., Blake, R.W., Fernandes, E., Nicholson, C.F. and Valentim, J.F. (2004). Soil, plant and cattle nutrient pools on pastures of the western Amazon of Brazil. Agriculture, Ecosystems and Environment (submitted).

Rueda, B., Blake, R.W., Nicholson, C.F., Fox, D.G., Tedeschi, L., Pell, A.N., Fernandes, E., Lee, D.R., Valentim, J.F. and da Costa, J. (2003). Production and economic potentials of cattle in pasturebased systems of the western Amazon region of Brazil. Journal of Animal Science 81:2923-2937.

Sala, O.E., Chapin III, F.S., Armesto, J.J., Berlow, E., Bloomfield, J., Dirzo, R., Huber-Sanwald, E., Huenneke, L.F., Jackson, R.B., Kinzig, A., Leemans, R., Lodge, D.M., Mooney, H.A., Oesterheld, M., Poff, N.L., Sykes, M.T., Walker, B.H., Walker, M. and Wall, D.H. (2000). Global biodiversity scenarios for the year 2100 . Science 287: 1770-1774.

Sekercioglu, C.H., Ehrlich, P.R., Daily, G.C., Aygen, D., Goerhring, D. and Sandi, R.F. (2002). Disappearance of insectivorous birds from tropical forest fragments. Proceedings National Academy of Science 99:263-267.

Sterman, J.D. (2000). Business dynamics: Systems thinking and modeling for a complex world. McGraw-Hill, USA.

Tedeschi, L.O., Fox, D.G., Pell, A.N., Lanna, D.P.D. and Boin, C. (2002). Development and evaluation of a tropical feed library for the Cornell Net Carbohydrate and Protein Model. Scientia Agricola 59(1): 1-18.

Thornton, P.K., and Hererro, M. (2001). Integrated crop-livestock simulation models for scenario analysis and impact assessment. Agricultural Systems 70:581-620.

Tilman, D. (1999). Global environmental impacts of agricultural expansion: The need for sustainable and efficient practices. Proceedings National Academy of Science 96:5995-6000.

Tilman, D., Fargione, J., Wolff, B., D'Antonio, C., Dobson, A., Howarth, R., Schindler, D., Schlesinger, W.H., Simberloff, D. and 
Swackhamer, D. (2001 a). Forecasting agriculturally driven global environmental change. Science 292:281-284.

Tilman, D., Reich, P.B., Knops, J., Wedin, D., Mielke, T. and Lehman, C. (2001 b). Diversity and productivity in a long-term grassland experiment. Science 294:843-845.

Vennix, J.A.M. (1996). Group model building: Facilitating team learning using system dynamics. John Wiley and Sons, Chichester, UK.

Vitousek, P.M., Mooney, H.A., Lubchenco, J. and Melillo, J.M. (1997). Human domination of Earth's ecosystems. Science 277:494499.

Vosti, S.A. (1995). Sustainability, growth, and poverty alleviation: Research and policy issues for tropical moist forests. Agriculture and environment: Bridging food production and environmental protection in developing countries. Edited by A.S.R. Juo and R. D. Freed. pp. 207-227. Special Publication 60, Soil Science Society of America.

Vosti, S.A. and Valentim, J. (1998). Foreward. In: Cattle, deforestation and development in the Amazon: An economic, agronomic and environmental perspective. (M.D. Faminow, Ed.) CAB International, Wallingford, UK, pp. vi-viii.

Wackernagel, M., Schulz, N. B., Deumling, D., Linares, A. C., Jenkins, M., Kapos, V., Monfreda, C., Loh, J., Myers, N., Norgaard, R. and Randers, J. (2002). Tracking the ecological overshoot of the human economy. Proceedings National Academy of Science 99:9266-9271.

Western, D. (2001). Human-modified ecosystems and future evolution. Proceedings National Academy of Science 98:5458-5465.

White, G. M., Boshier, D. H. and Powell, W. (2002). Increased pollen flow counteracts fragmentation in a tropical dry forest: An example from Swietenia humilis Zuccarini. Proceedings National Academy of Science 99:2038-2042. 